Irmina Miernicka ${ }^{1}$

http://dx.doi.org/10.18778/8088-306.2.13

\title{
Wpływ otwarcia likwidacji spółki kapitałowej na umowny stosunek pracy z członkiem zarządu
}

\section{Uwagi wprowadzające}

Likwidacja spółki kapitałowej ma na celu spieniężenie jej majątku oraz zakończenie bieżących spraw spółki. W przypadku spółek kapitałowych, przeprowadzenie likwidacji jest warunkiem koniecznym do rozwiązania spółki i wykreślenia jej z rejestru. Sposób prowadzenia likwidacji regulują odpowiednie przepisy ustawy z dnia 15 września 2000 r. kodeks spółek handlowych².

Zarząd w spółkach kapitałowych jest organem wykonawczym, którego głównym zadaniem jest prowadzenie spraw i reprezentacja spółki. Może on składać się z jednego lub większej liczby członków, którymi mogą być zarówno wspólnicy, jak i osoby trzecie. Z chwilą powołania zarząd uzyskuje legitymację do działania - staje się uprawniony do podejmowania czynności za spółkę w ramach swoich kompetencji. Między członkiem zarządu a spółką powstaje wówczas stosunek organizacyjny (korporacyjny) 3 .

Popularną praktyką jest zatrudnianie członków zarządu spółek kapitałowych na podstawie stosunku pracy. Jest to dopuszczalne z uwagi na brzmienie art. $203 \S 1$ i $370 \S 1$ k.s.h., zgodnie z którymi odwołanie członka zarządu nie pozbawia go roszczeń ze stosunku pracy oraz art. $378 \S 1$ k.s.h., który przyznaje radzie nadzorczej kompetencje do ustalania wynagrodzenia członków zarządu zatrudnionych na podstawie umowy o pracę lub innej umowy. Linia orzecznicza Sądu Najwyższego jasno wskazuje, iż stosunek pracy jest odrębnym stosunkiem prawnym od członkostwa w zarządzie spółki (stosunku korporacyjnego) ${ }^{4}$. W przypadku stosunku pracy, członek zarządu jest osobą trzecią względem spółki i o treści jego praw oraz ewentualnych roszczeń

\footnotetext{
1 Doktorantka, Uniwersytet Łódzki, Wydział Prawa i Administracji, Katedra Prawa Pracy. Radca prawny.

2 Ustawa z dnia 15 września 2000 r. Kodeks spółek handlowych, Dz.U.2013.1030 z dnia 6 września 2013 r., zw. dalej k.s.h.

${ }^{3}$ R. Szczęsny, Zarząd w spółkach kapitałowych ze szczególnym uwzględnieniem ograniczeń kompetencji członków zarzq̨du, Kraków 2004, s. 43-45.

4 Tak m.in. wyrok Sądu Najwyższego z dnia 25 listopada 1997 r., I PKN 388/97, OSNAPiUS 1998Nr 18, poz. 540; wyrok Sądu Najwyższego z dnia 19 czerwca 2012 r., II UK 282/11, LEX 1229811, wyrok Sądu Najwyższego z dnia 6 kwietnia 2011 r., II PK 255/10, LEX 863881. Z uwagi na temat niniejszego artykułu autorka nie będzie szerzej
} 
pracowniczych decyduje treść stosunku pracy oraz przepisy prawa pracy. W drugim przypadku, członek zarządu jest członkiem organu spółki, a więc o poprawności jego powołania, treści obowiązków oraz roszczeniach decyduje umowa spółki, bądź uchwała wspólników go powołująca, a także przepisy Kodeksu spółek handlowych ${ }^{5}$. Zawarcie umowy o pracę nie ma jednak wpływu na zakres uprawnień, obowiązków i odpowiedzialności członka zarządu jako piastuna organu osoby prawnej ${ }^{6}$.

Należy zwrócić uwagę na pewną atypowość stosunku pracy członków zarządu spółek kapitałowych. Wynika ona ze szczególnej roli, jaką członkowie zarządu pełnią w strukturze organizacyjnej spółek kapitałowych, a przejawia się przede wszystkim ograniczeniem kierownictwa pracodawcy, brakiem pracowniczego podporządkowania rozumianego sensu stricto, a także przesunięciem ryzyka gospodarczego z pracodawcy na pracowników-członków zarządu 7 .

W sytuacji otwarcia likwidacji spółki kapitałowej powstaje pytanie o to, jaki wpływ będzie ono miało na stosunek pracy nawiązany z członkiem zarządu tej spółki na podstawie umowy o pracę. Czy umowa o pracę zawarta z członkiem zarządu spółki kapitałowej obowiązuje nadal po otwarciu likwidacji spółki i objęciu funkcji likwidatora przez członka zarządu, czy przekształca się z mocy prawa w umowę o pracę z likwidatorem, czy też stosunek pracy ustaje, a jeśli tak, to na jakiej podstawie? W niniejszym opracowaniu autorka postara się udzielić odpowiedzi na powyższe pytania.

omawiać prezentowanych przez doktrynę poglądów oraz kontrowersji związanych ze statusem pracowniczym oraz dopuszczalnymi formami zatrudnienia pracowniczego członków zarządu spółek kapitałowych. Więcej na ten temat-zob. m.in. Z. Kubot, Status pracowniczy członków zarzq̨du spółek kapitałowych, „Praca i Zabezpieczenie Społeczne" (dalej: PiZS) 3/1993; Ł. Pisarczyk, Podstawy nawiq̨zania stosunku pracy z członkiem zarządu spółki kapitałowej, PiZS 10/1998; P. Skorupa, Postawy prawne zatrudnienia członków zarządu w spółkach kapitałowych, „Prawo Spółek” 05/1998.

5 Wyrok Sądu Najwyższego z dnia 15 marca 2006 r., II PK 167/05, LEX 232585.

6 Z. Kubot, Umowy o pracę z członkami zarządu spółek kapitałowych, PiZS 1/95, s. 36.

7 Więcej na ten temat - zob. T. Duraj, Atypowość stosunku pracy członków zarzq̨du spółek kapitałowych - wybrane problemy prawne, [w:] „Prawo pracy, Biblioteka Studenckich Poradni Prawnych" pod red. K. Stefańskiego, Warszawa 2008 s. 132-144 i literatura tam powoływana. 


\section{Umowa o pracę z członkiem zarządu spółki kapitałowej - uwagi ogólne}

Samo powołanie na członka zarządu spółki nie powoduje powstania stosunku pracy pomiędzy nim a spółką8. Jednym ze sposobów nawiązania stosunku pracy, określonym w art. 2 Kodeksu pracy ${ }^{9}$, jest zawarcie umowy o pracę. Sposób zawarcia z członkiem zarządu umowy o pracę reguluje art. $210 \S 1$ k.s.h., zgodnie z którym w umowie między spółką a członkiem zarządu spółkę reprezentuje rada nadzorcza lub pełnomocnik powołany uchwałą zgromadzenia wspólników. Należy mieć również na względzie odpowiednie przepisy kodeksu pracy umowa o pracę powinna być zawarta na piśmie, wyraźnie wskazywać takie elementy jak rodzaj pracy, miejsce i czas jej wykonywania, wynagrodzenie, wymiar czasu pracy oraz termin jej rozpoczęcia. Umowa o pracę zawierana pomiędzy spółką a członkiem zarządu może zostać zawarta zarówno na czas określony, jak i nieokreślony. W literaturze podkreśla się natomiast, że charakter pracy członków zarządu przemawia za niezawieraniem z tą grupą pracowników umów o pracę na okres próbny ${ }^{10}$.

Najbardziej optymalnym rozwiązaniem, uwzględniającym specyficzny rodzaj pracy świadczonej przez członka zarządu oraz jej okresowy charakter, jest zawarcie umowy o pracę na czas określony. Jak podnosi Z. Kubot, funkcjonalność stosunku pracy członka zarządu wobec stosunku organizacyjnego wymaga, żeby czas trwania stosunku pracy był dostosowany do czasu pełnienia funkcji piastuna organu zarządzającego ${ }^{11}$. Aby jednak w pełni pogodzić moment wygaśnięcia mandatu członka zarządu z chwilą rozwiązania stosunku pracy, należy prawidłowo określić czas, na jaki umowa o pracę zostaje zawarta. Stosownie do art. $202 \S 1$ oraz $\S 2$ i art. $369 \S 4$ k.s.h., wygaśnięcie mandatu członka zarządu co do zasady powinno nastąpić w dniu odbycia zgromadzenia wspólników (walnego zgromadzenia akcjonariuszy) zatwierdzającego sprawozdanie finansowe za ostatni pełny rok obrotowy pełnienia funkcji, jednak precyzyjne wyznaczenie tej daty jest w większości przypadków niemożliwe. W związku z tym, w literaturze przedmiotu proponuje się, aby umowa o pracę została zawarta do dnia odbycia zgromadzenia udzielającego absolutorium członkom zarządu

\footnotetext{
8 R. Szczęsny, Zarzq̨d..., s. 70.

${ }_{9}^{9}$ Ustawa z dnia 26 czerwca 1974 r. Kodeks pracy, Dz.U.2014.1502 z dnia 4 listopada 2014 r., zw. dalej k.p.

10 R. Szczęsny, Zarzq̨d..., s. 72; Ł. Pisarczyk, Zatrudnianie członków zarzq̨du spółek kapitałowych, Warszawa 2000, s. 34-40.

11 Z. Kubot, Umowa..., s. 39
} 
z wykonania ich obowiązków za konkretny rok obrotowy. Jest to bowiem zdarzenie obiektywne i możliwe do ustalenia w czasie ${ }^{12}$. Zatrudniając członka zarządu na podstawie umowy o pracę na czas określony i ustalając czas jej trwania należy mieć również na względzie ograniczenia wynikające z nowelizacji kodeksu pracy, która weszła w życie 22 lutego 2016 r. ${ }^{13}$. Najważniejsze zmiany wynikające z nowelizacji to ustanowienie limitu trzech umów zawieranych na czas określony (czwarta umowa pomiędzy tym samym pracownikiem a pracodawcą będzie już zawarta na czas nieokreślony) oraz 33-miesięcznego limitu zatrudnienia na umowę o pracę na czas określony. To drugie ograniczenie co prawda nie musi być stosowane, gdy praca jest wykonywana przez okres kadencji, jednak wówczas pracodawca ma obowiązek powiadomić o zawarciu takiej umowy okręgowego inspektora pracy, podając jednocześnie przyczynę jej zawarcia, która musi również zostać wpisana do umowy o pracę.

Możliwe jest także zawarcie z członkiem zarządu umowy o pracę na czas nieokreślony. Pomimo wyłaniających się w świetle tego, co zostało wspominane powyżej, oczywistych wad takiego rozwiązania dla pracodawcy ${ }^{14}$, umowy takie funkcjonują często w obrocie prawnym. Sąd Najwyższy w jednym ze swoich orzeczeń podniósł, iż kadencyjność organów spółki prawa handlowego nie oznacza powinności zawierania przez spółkę z osobami pełniącymi funkcję jej organów umów o pracę na czas określony równy okresowi kadencji15. Odnosząc się natomiast do możliwości powołania członka zarządu na czas nieoznaczony Sąd Najwyższy stwierdził, że w takiej sytuacji członek zarząd będzie pełnić swoją funkcję do czasu, gdy nie spełni się którakolwiek z przesłanek wygaśnięcia mandatu, a w szczególności dopóki nie zostanie odwołany uchwałą wspólników ${ }^{16}$. W przypadku zatem zatrudnienia członka zarządu na podstawie umowy o pracę na czas nieokreślony, przysługiwać mu będą wszelkie uprawnienia wynikające z powszechniej i szczególnej ochrony przed wypowiedzeniem.

\footnotetext{
12 Ibidem, s. 39-40.

13 Ustawa z dnia 25 czerwca 2015 r. o zmianie ustawy - Kodeks pracy oraz niektórych innych ustaw, Dz.U.2015.1220 z dnia 21 sierpnia 2015 r.

14 Więcej na ten temat - zob. m.in.: T. Duraj, Atypowość..., s. 140-144; Z. Kubot, Umowy..., s. 41-43.

15 Wyrok Sądu Najwyższego z dnia 10 sierpnia 2000 r., I PKN 758/99, LEX 45359.

16 Wyrok Sądu Najwyższego z dnia 12 października 2011 r., II CSK 29/11, LEX 1043996.
} 


\section{Otwarcie likwidacji a stosunek pracy z członkiem zarządu}

Jak zostało zaznaczone wcześniej, w przypadku spółek kapitałowych przeprowadzenie likwidacji jest warunkiem koniecznym do rozwiązania spółki i wykreślenia jej z rejestru. Likwidacja ma na celu spieniężenie majątku spółki oraz zakończenie jej bieżących spraw. Stosownie do art. $274 \S 1$ k.s.h. i 461 § 1 k.s.h., otwarcie likwidacji następuje z dniem uprawomocnienia się orzeczenia o rozwiązaniu spółki przez sąd, powzięcia przez wspólników/walne zgromadzenie uchwały o rozwiązaniu spółki lub zaistnienia innej przyczyny jej rozwiązania. W czasie likwidacji spółka zachowuje osobowość prawną, a do jej firmy dodaje się oznaczenie „w likwidacji”. Z punktu widzenia niniejszego opracowania istotne jest brzmienie art. $276 \S 1$ i $463 \S 1$ k.s.h., zgodnie z którymi likwidatorami są członkowie zarządu, chyba że umowa/statut spółki lub uchwała wspólników/walnego zgromadzenia stanowi inaczej. Możliwe są zatem następujące sposoby ustanowienia likwidatorów:

- w umowie/statucie spółki, która/który wprost wskazuje osoby oraz ich liczbę albo tryb ich powołania;

- uchwałą wspólników/walnego zgromadzenia, która również może określać zarówno liczbę, tryb, jak i powoływać określone osoby;

- ex lege - na podstawie przywołanych przepisów, jeżeli umowa/statut spółki ani uchwała nie stanowią inaczej, są nimi członkowie ostatniego zarządu. Nie ma wówczas konieczności podejmowania przez wspólników/walne zgromadzanie uchwały o ich powołaniu;

- przez sąd, jeśli orzeka on o rozwiązaniu spółki (art. 276 § 3 i 463 § 3 k.s.h. ${ }^{17}$.

Konkludując, $\mathrm{w}$ braku odmiennych postanowień umowy/statutu spółki lub uchwały wspólników/walnego zgromadzenia, z chwilą otwarcia likwidacji mandat członków zarządu wygasa z mocy prawa, a dotychczasowi członkowie zarządu stają się likwidatorami. W konsekwencji należy przyjąć, że mandat dotychczasowego członka zarządu wygasa $\mathrm{z}$ mocy prawa $\mathrm{z}$ chwilą otwarcia likwidacji ${ }^{18}$. Podobnie jak

17 J.P. Naworski, Komentarz do art. 276 i 463 k.s.h., [w:] „Kodeks spółek handlowych. Komentarz" pod red. R. Potrzeszcza i T. Siemiątkowskiego, LEX dostęp z dnia 05.10.2015 r.

18 Ibidem; inaczej w tej kwestii A. Witosz, Kompetencje wspólników prowadzacych sprawy spółki. Pozycja prawna zarządu w spółkach handlowych w likwidacji, „Przegląd Prawa Handlowego" 8/2009, zdaniem którego a contrario do brzmienia art. $202 \S 4$ k.s.h., mandat członka zarządu nie wygasa z chwilą otwarcia likwidacji lub ustanowienia likwidatorów, lecz konieczne jest jego odwołanie; A. Kidyba, Spółka z ograniczonq odpowiedzialnościq̨. Komentarz, Warszawa 2009, s. 830 stoi natomiast na stanowisku, że skutek ten następuje dopiero z chwilą wpisu do rejestru. 
w przypadku członka zarządu, podstawą pełnienia funkcji likwidatora jest przede wszystkim stosunek organizacyjny, a jego obowiązki wynikają wprost z przepisów kodeksu spółek handlowych. W sytuacji stania się likwidatorem z mocy prawa powstaje pytanie o to, jaki wpływ ma otwarcie likwidacji na umowę o pracę zawartą z członkiem zarządu przed uzyskaniem przez niego statusu likwidatora. Czy obowiązuje ona nadal, czy przekształca się z mocy prawa w umowę o pracę z likwidatorem, czy też stosunek pracy ustaje, a jeśli tak, to na jakiej podstawie?

W literaturze przedmiotu przyjmuje się, że ustanie stosunku pracy jest następstwem dokonanej czynności prawnej (złożenia oświadczenia lub oświadczeń woli) albo następuje z mocy prawa wskutek wystąpienia wskazanego przez ustawodawcę zdarzenia niebędącego czynnością prawną ${ }^{19}$. Kodeks pracy nie przewiduje innych sposobów zakończenia zatrudnienia opartego na umowie o pracę. Przepis art. $30 \S 1$ k.p. w znowelizowanym brzmieniu stanowi, że umowa o pracę rozwiązuje się na mocy porozumienia stron, przez oświadczenie jednej ze stron z zachowaniem okresu wypowiedzenia (rozwiązanie umowy o pracę za wypowiedzeniem), przez oświadczenie jednej ze stron bez zachowania okresu wypowiedzenia (rozwiązanie umowy o pracę bez wypowiedzenia) albo z upływem czasu, na który była zawarta. Stosunek pracy ustaje wówczas z woli stron, które z góry określiły datę albo zdarzenie rozwiązujące umowę i nie ma potrzeby dodatkowego powiadamiania drugiej strony, a zwłaszcza pracownika, o nadejściu terminu rozwiązania stosunku pracy ${ }^{20}$. Powołany przepis zawiera zatem zamknięty katalog trybów rozwiązania umowy o pracę. Do ustania stosunku pracy może dojść również przez jego wygaśnięcie w przypadkach określonych w kodeksie pracy oraz w innych przepisach. Dochodzi do tego m.in. w takich sytuacjach jak śmierć pracownika, śmierć pracodawcy, tymczasowe aresztowanie pracownika czy

\footnotetext{
19 W. Sanetra, Komentarz do art. 63 k.p. [w:] „Kodeks pracy. Komentarz, wyd. III.” pod red. J. Iwulskiego, LEX dostęp z dn. 05.10.2015 r.

20 Zgodnie z wyrokiem Sądu Najwyższego z dnia 11 kwietnia 2000 r., I PKN 575/99, LEX 48770, brak oświadczeń pracodawcy co do dalszego trwania umowy o pracę zawartej na czas określony po jej rozwiązaniu nie może być rozumiany jako wola kontynuowania zatrudnienia. Warunkiem koniecznym uznania, że po rozwiązaniu się umowy terminowej doszło do nawiązania nowego stosunku pracy, jest ustalenie, że pracodawca miał zamiar zatrudnić byłego pracownika na określonym stanowisku. Wykonywanie przez byłego pracownika w ciągu kilku dni czynności pracowniczych bez wiedzy pracodawcy nie świadczy o zgodnym zamiarze nawiązania umowy o pracę.
} 
niezgłoszenie przez niego powrotu do pracy w ciągu 7 dni po rozwiązaniu stosunku pracy z wyboru u innego pracodawcy ${ }^{21}$. Redakcja przepisu art. 63 k.p. oraz poglądy przedstawicieli doktryny wskazują, że wygaśnięcie stosunku pracy może nastąpić wyłącznie w sytuacjach ściśle określonych przez prawo, których nie można traktować rozszerzająco ${ }^{22}$. Mając na względzie powyższe należy stwierdzić, że otwarcie likwidacji nie jest zdarzeniem powodującym wygaśnięcie stosunku pracy z mocy prawa. Również Sąd Najwyższy w wyroku z dn. 5 września 2001 r. ${ }^{23}$ stanął na stanowisku, że likwidacja pracodawcy nie jest zdarzeniem powodującym wygaśnięcie umowy o pracę ${ }^{24}$.

${ }^{21}$ Poza wymienionymi przypadkami, wynikającym z kodeksu pracy, można odnaleźć inne normy, które wiążą wygaśnięcie stosunku pracy z pewnymi zdarzeniami, np. art. 122 ust. 1 ustawy z dnia 21 listopada 1967 r. o powszechnym obowiązku obrony Rzeczypospolitej Polskiej (Dz. U. z 2012 r., poz. 461 ze zm.) przewiduje wygaśnięcie stosunku pracy $\mathrm{w}$ przypadku niezgłoszenia przez pracownika powrotu do pracy w okresie trzydziestu dni od zwolnienia z zasadniczej służby wojskowej lub art. 186 $\S 1$ ustawy z dnia16 września 1982 r.-Prawo spółdzielcze (Dz. U. z 2003 r. Nr 188, poz. 1848 ze zm), zgodnie z którym wygaśnięcie stosunku pracy następuje w razie ustania członkostwa w spółdzielni pracy.

22 Tak m.in. M. Romer, Komentarz do art. 63 k.p., [w:] „Prawo pracy. Komentarz, wyd. V", LEX dostęp z dn. 05.10.2015 r. W literaturze pojawia się jednak dyskusja nad tym, czy katalog ten ma rzeczywiście charakter zamknięty i czy do zobowiązaniowego stosunku pracy można stosować przepisy prawa cywilnego dotyczące wygaśnięcia zobowiązania - zob. M. Gersdorf, Komentarz do art. 63 k.p.. [w:] „Kodeks pracy. Komentarz” pod red. Z. Salwy, LEX dostęp z dn. 05.10.2015 r.

23 Wyrok Sądu Najwyższego z dnia 5 września 2001 r., I PKN 830/00, LEX 49684.

24 Zob. również A. Tomanek, Glosa do wyroku SN z dn. 5 września 2001r., I PKN 830/00, OSP 2004/4/46.

Stan faktyczny dotyczył co prawda wykreślenia osoby fizycznej z ewidencji działalności gospodarczej, co zdaniem Sądu nie jest likwidacją pracodawcy w rozumieniu art. $41^{1}$ k.p. Jednak stosując tezę SN do likwidacji pracodawcy będącego spółką kapitałową należy wywieść, iż nawet przeprowadzenie likwidacji spółki i wykreślenie jej z Krajowego Rejestru Sądowego nie jest zdarzeniem powodującym wygaśnięcie stosunku pracy, a zakończenie stosunku pracy w tym przypadku wymaga rozwiązania umowy o pracę w sposób przewidziany prawem. Przepisy kodeksu pracy stanowią bowiem wprost, że wygaśnięcie stosunku pracy następuje z chwilą śmierci pracodawcy. Śmierć może dotyczyć jedynie osoby fizycznej, a enumeratywny katalog przyczyn powodujących wygaśnięcie stosunku pracy nie pozwala na interpretację rozszerzającą. Takie rozumowanie, chociaż zgodne z literą prawa, może w mojej ocenie prowadzić do wielu komplikacji natury praktycznej. Może się bowiem zdarzyć, że w trakcie likwidacji nie zostanie rozwiązana umowa o pracę zawarta np. z likwidatorem, a spółka zostanie wykreślona z Krajowego Rejestru Sądowego i utraci swój byt prawny. Powstaje wówczas pytanie, co dzieje się z niezakończonym stosunkiem pracy. Czy nie należałoby stosować w drodze analogii art. $63^{2}$ k.p. albo na podstawie art. 300 k.p. przepisów kodeksu cywilnego dotyczących wygaśnięcia zobowiązania? Kwestia ta pozostaje otwarta do dyskusji. 
Jak to już zostało wspomniane, członek zarządu może być w każdym czasie odwołany uchwałą wspólników, nie pozbawia go to jednak roszczeń ze stosunku pracy. W przypadku odwołania członka zarządu zatrudnionego na podstawie umowy o pracę lub wygaśnięcia jego mandatu w inny sposób, ustaje jedynie więź organizacyjna łącząca członka zarządu ze spółką. Nie wpływa to bezpośrednio na stosunek pracy łączący byłego członka zarządu i spółkę, co wynika z odrębności tych dwóch stosunków, polegającej m.in. na tym, że czynności dokonane w odniesieniu do stosunku członkostwa nie wywierają automatycznie wpływu na stosunek prawny dotyczący pełnienia funkcji, ale wymagają dodatkowych czynności. Stosunek pracy rozwiązuje się zatem na podstawie przepisów prawa pracy25. W związku z tym, w wypadku otwarcia likwidacji i objęcia funkcji likwidatora przez dotychczasowego członka zarządu, należałoby rozwiązać z nim umowę o pracę na mocy porozumienia stron albo z zachowaniem terminów wypowiedzenia. Niewątpliwie jest to uzasadniona przyczyna wypowiedzenia umowy o pracę 26 .

Możliwe jest również dokonanie zmiany warunków pracy i płacy w drodze wypowiedzenia zmieniającego dokonanego przez pracodawcę. Pozwoli to dostosować rodzaj wykonywanej przez likwidatora pracy do zakresu jego obowiązków. Ze względu na zobowiązaniowy charakter stosunku pracy niemożliwe jest bowiem dokonywanie zmian w jego treści jednostronnie. Uregulowana w art. 42 k.p. instytucja wypowiedzenia warunków pracy i płacy, powszechnie zwana wypowiedzeniem zmieniającym, umożliwia modyfikację dotychczasowych warunków zatrudnienia bez rozwiązywania stosunku pracy ${ }^{27}$. Wypowiedzenie zmieniające może być dokonane jedynie przez pracodawcę i dochodzi do niego poprzez wypowiedzenie dotychczasowych warunków pracy lub płacy i przyjęcie przez pracownika zaproponowanych mu nowych warunków. Konstrukcja ta zawiera w istocie dwa oświadczenia woli pracodawcy - jedno zmierzające do zakończenia zatrudnienia na dotychczasowych warunkach oraz drugie, w którym pracownikowi przedstawia się nowe warunków pracy lub płacy ${ }^{28}$. Między tymi oświadczeniami występuje nierozerwalny związek, jednak z przepisów kodeksu pracy nie wynika, że czynności te muszą być podjęte

\footnotetext{
25 J. P. Naworski, Komentarz do art. 203 k.s.h., [w:] „Kodeks spółek...”.

26 Wyrok Sądu Najwyższego z dnia 25 listopada 1997 r., I PKN 388/97, LEX 33570, wyrok Sądu Najwyższego z dnia 26 stycznia 2000 r., I PKN 479/99, LEX 41192.

27 M. Romer, Komentarz do art. 42 k.p., [w:] „Prawo pracy...”.

28 W. Sanetra, Komentarz do art. 42 k.p., [w:] „Kodeks pracy...”.
} 
jednocześnie, a więc jest możliwe ich rozdzielenie w czasie $^{29}$. Warunki te muszą być jednak określone precyzyjnie - nie wystarczy ogólne poinformowanie pracownika, że ulegną one zmianie. Dodatkowo, pracodawca jest obowiązany pouczyć pracownika, że przed upływem połowy okresu wypowiedzenia powinien on złożyć oświadczenie o odmowie przyjęcia nowych warunków. W przeciwnym razie uznaje się, że pracownik warunki te akceptuje. Jeżeli natomiast pracownik odmówi podjęcia pracy na nowych warunkach, oznacza to, że z upływem pełnego okresu wypowiedzenia stosunek pracy ulegnie rozwiązaniu. Takie zakończenie stosunku pracy traktowane jest podobnie jak rozwiązanie $\mathrm{w}$ drodze wypowiedzenia dokonanego przez pracodawcę 30 .

Powstaje jednak pytanie, co w sytuacji, gdy nastąpiło otwarcie likwidacji, członek zarządu, zatrudniony na podstawie umowy o pracę, stał się ex lege likwidatorem i przystąpił do wykonywania swoich nowych obowiązków, chociaż zawarta z nim umowa o pracę nie uległa zmianie. Zostało już wykazane, że w sytuacji otwarcia likwidacji taki stosunek pracy nie rozwiązuje się ani nie wygasa. Z drugiej strony, $\mathrm{z}$ uwagi na różny charakter pełnionych funkcji, nie jest możliwe świadczenie pracy w oparciu o dotychczasową umowę. Wówczas, w mojej ocenie, należy przyjąć, że doszło do zmiany warunków pracy w drodze porozumienia zmieniającego. Instytucja ta nie jest wprost uregulowana w kodeksie pracy, jednak jej dopuszczalność wynika ze zobowiązaniowego charakteru stosunku pracy oraz swobody stron umowy o pracę, ograniczonej jedynie przez przepisy prawa, właściwość stosunku pracy oraz zasady współżycia społecznego. Zmiana warunków pracy lub płacy za porozumieniem stron wymaga zgodnego oświadczenia woli obu stron umowy o pracę i może dotyczyć każdego rodzaju umowy oraz wszelkich postanowień umownych. Może również być zawarte w każdy czasie trwania stosunku pracy, w tym w trakcie urlopu lub zwolnienia lekarskiego pracownika bądź innej jego nieusprawiedliwionej nieobecności w pracy31. Co więcej, porozumienie stron zmieniające warunki płacy nie podlega ocenie według reguł określonych $\mathrm{w}$ art. 42 $\S 2$ k.p. ${ }^{32}$

\footnotetext{
${ }^{29}$ Ibidem.

${ }^{30}$ M. Romer, Komentarz...

${ }^{31}$ R. Sadlik, Porozumienie zmieniające jako sposób modyfikacji warunków zatrudnienia, „Monitor Prawa Pracy” 6/2010.

32 Wyrok Sądu Najwyższego z dnia 8 kwietnia 1998 r., I PKN 29/98, LEX 35630.
} 
W praktyce porozumienie zmieniające najczęściej zawierane jest $w$ formie pisemnej, np. $w$ formie aneksu do umowy o pracę, ale nie jest to forma wymagana przez prawo. W związku z tym, skuteczne będzie również porozumienie dokonane ustnie, a nawet per facta concludentia. Jest to bowiem w istocie oferta zgodnej zmiany warunków pracy lub płacy, do której stosuje się odpowiednio, zgodnie z art. 300 k.p., przepisy kodeksu cywilnego ${ }^{33}$, co oznacza, że pracownik może przyjąć propozycję pracodawcy poprzez wyrażenie zgody, uzewnętrznionej w sposób wyraźny. W literaturze przedmiotu przyjmuje się, że zgoda ta może być również dorozumiana i będzie ją stanowiło takie zachowanie się pracownika, które świadczy o tym, że aprobuje on propozycję pracodawcy dotyczącą zmiany warunków zatrudnienia, np. podjęcie pracy na nowym stanowisku ${ }^{34}$.

Mając na uwadze powyższe należy stwierdzić, że w sytuacji, gdy członek zarządu, zatrudniony na podstawie umowy o pracę, stał się ex lege likwidatorem i przystąpił do wykonywania swoich nowych obowiązków, chociaż zawarta z nim umowa o pracę nie została wypowiedziana ani formalnie nie uległa zmianom, doszło pomiędzy stronami stosunku pracy do zawarcia per facta concludentia porozumienia zmieniającego warunki pracy. Pracodawca, poprzez swoją bezczynność przejawiającą się niedokonaniem wypowiedzenia umowy o pracę albo wypowiedzenia zmieniającego, złożył pracownikowi dorozumianą ofertę zmiany rodzaju wykonywanej pracy, na którą pracownik wyraził dorozumianą zgodę, przystępując do pracy na nowym stanowisku. Podobne rozumowanie i argumentację przedstawił także Sąd Najwyższy w uzasadnieniu wydanego niedawno Wyroku z dnia 27 stycznia 2016 r. ${ }^{35}$

\section{Podsumowanie}

Konkludując należy podkreślić, że stosunek organizacyjny i stosunek pracy łączący członka zarządu ze spółką kapitałową to dwa różne i niezależne od siebie stosunki prawne. W związku z tym, otwarcie likwidacji spółki i związane z tym wygaśnięcie mandatu członka zarządu nie wpływa bezpośrednio na stosunek pracy z tym członkiem. Brak jest w przepisach prawa odpowiednich regulacji, na mocy których

\footnotetext{
33 Wyrok Sądu Najwyższego z dnia 4 października 2000 r., I PKN 58/00, LEX 52240. 34 R. Sadlik, Porozumienie....

35 Wyrok Sądu Najwyższego z dnia 27 stycznia 2016 r., I UK 40/15, http://www.sn.pl/sites/orzecznictwo/orzeczenia3/i\%20uk\%2040-15-1.pdf dostęp $\mathrm{z}$ dn. 04.05.2016 r.
} 
doszłoby do wygaśnięcia stosunku pracy w takiej sytuacji. Aby go zakończyć, należy podjąć czynności prowadzące do rozwiązania umowy o pracę, przewidziane w kodeksie pracy. Możliwe jest także zawarcie porozumienia zmieniającego warunki pracy i płacy albo dokonanie przez pracodawcę wypowiedzenia dotychczasowych warunków pracy i płacy. 